\title{
EVALUATION OF MANAGEMENT OF RESPIRATORY DISTRESS IN NEWBORNS OVER 34 WEEKS OF GESTATIONAL AGE IN HOSPITAL OF
}

ARPAJON

Ekaterina Kutsia, pediatrician, Hospital center of Arpajon, France

Background and aims:

Respiratory distress (RD) is one of the principal cause of mortality and morbidity in neonatology. In 2016 new guideline was established by GENIF, based on recommendations of ILCOR 2015. The aim of this study was to evaluate if new protocol was carefully implicated and respected in our neonatology unit.

\section{Method}

We made a retrospective study of the data for the period of $01 / 03 / 2016-01 / 03 / 2017$ in maternity of type $2 A$, with annual delivery rate of 1400 newborns. Only newborns with $\mathrm{RD}$ and $\geq 34$ weeks of gestation age were included. Newborns with genetic abnormalities or malformations which could cause RD were excluded.

We divided our population into 3 groups by severity of RD (image1).

We analyzed the severity of $\mathrm{RD}$ on $\mathrm{M} 15, \mathrm{H} 2$ and $\mathrm{H} 4$ of life, the age of intervention by ventilation non invasive (VNI), the time of call for transfer.

Results

In total, 53 cases were studied, 46 of early-onset, 7 of late-onset $\mathrm{RD}$.

In $87 \%$ RD was immediate and nCPAP was started before M15.

More RD was severe before M15 more nCPAP was prolonged. $(p=0.14)$

Severe $R D$ were transferred all in time (IQR=2.25h).
7 newborns had a late-onset RD and CPAP was started later and it lasted more than 4 hours, 1 newborn was transferred in correct timing according to GENIF.

\section{Conclusion}

In $37 / 46(70 \%)$ of early-onset respiratory distress the management was efficient with total respect of GENIF protocol, while the $\mathrm{RD}$ of late-onset, which has in most of time the worst outcome, the rules are almost never respected (1/7).

Image 1. Classification of DR by severity

\begin{tabular}{|l|l|l|l|l|l|}
\hline RD & Respiration & SOIWB & SpO2 & $\begin{array}{l}\text { Silverman } \\
\text { score }\end{array}$ & FiO2 \\
\hline Mild & $\begin{array}{l}\text { Isolated } \\
\text { tachypnoea }\end{array}$ & $\begin{array}{l}\text { Moderate } \\
\text { without } \\
\text { grunt }\end{array}$ & $\begin{array}{l}\geq 92 \% \text { on } \\
\text { room air }\end{array}$ & $<4$ & $21 \%$ \\
\hline Moderated & Polypnoea & grunt + autre & $\begin{array}{l}<92 \% \text { on } \\
\text { room air }\end{array}$ & $4-6$ & $21 \%$ à 40\% \\
\hline Severe & $\begin{array}{l}\text { Increased or } \\
\text { markedly } \\
\text { reduced RR }\end{array}$ & $\begin{array}{l}\text { Persisting } \\
\text { grunting }\end{array}$ & $\begin{array}{l}\text { Désaturation, } \\
\text { oxygen } \\
\text { dependance }\end{array}$ & $>6$ & $\begin{array}{l}>40 \% \\
+ \\
\text { hemodynami } \\
\text { c instability }\end{array}$ \\
\hline
\end{tabular}

REFERENCES:

1. Sweet, David G; European Consensus Guidelines on the Management of Respiratory Distress Syndrome - 2016 Update; Neonatology 2017;111:107-125 DOI: 10.1159/000448985

2. Edwards, Martin O; Respiratory Distress of the Term Newborn Infant, Paediatric Respiratory Reviews, 14 (2013) 29-37

3. Jonathan Wylliea, Jos Bruinenberg, Charles Christoph Roehr, Mario Rüdiger, Daniele

Trevisanutoc, Berndt Urlesberger; European Resuscitation Council Guidelines for Resuscitation 2015; Resuscitation 95 (2015) 249-263

4. Godde Francis, réanimation du nouveau-né en salle de naissance, 2ème édition,p130; 2016

\section{GENIF protocol}

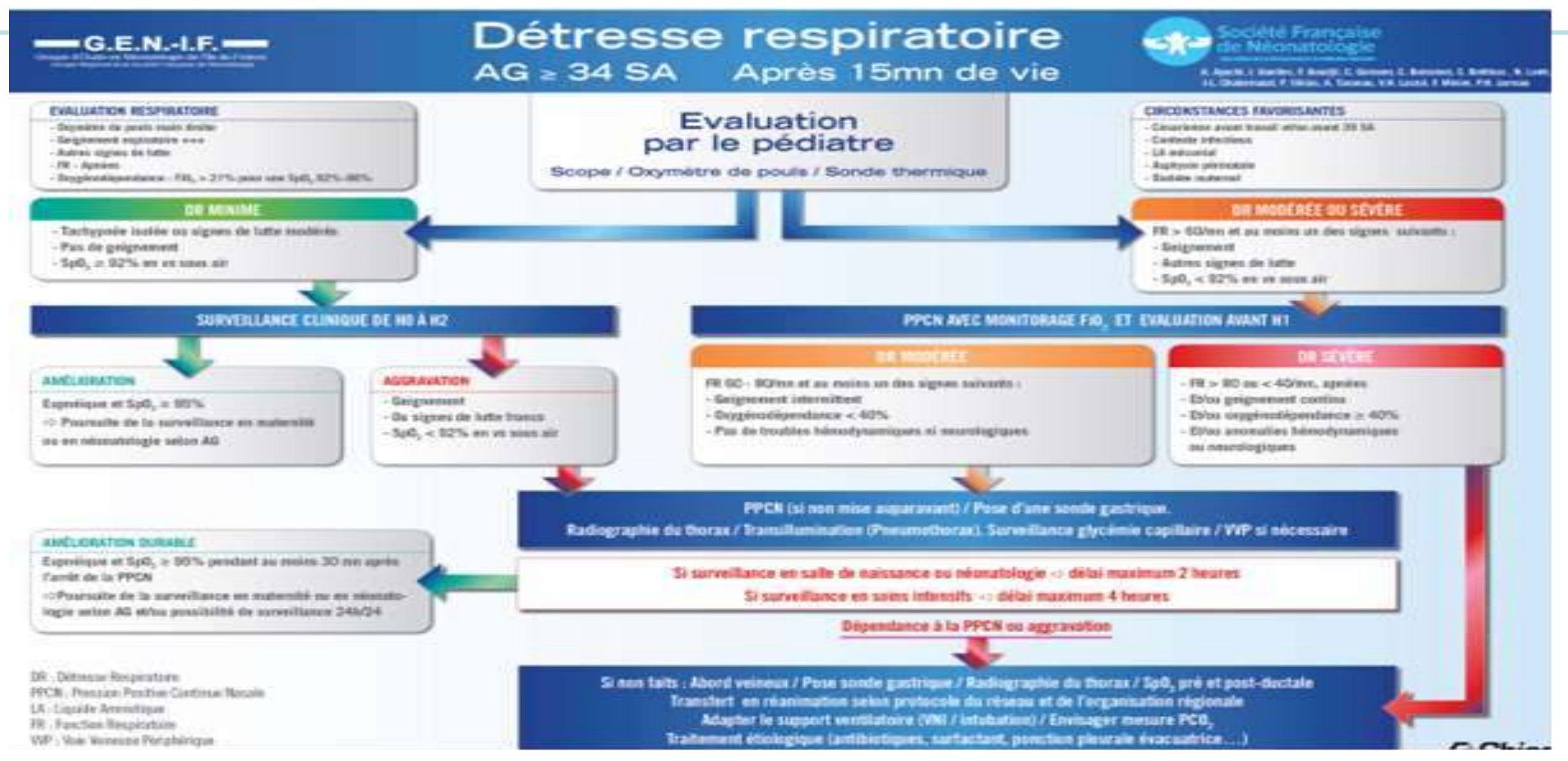

